\title{
OXYGEN CONSUMPTION, OXYGEN DEBT AND LACTIC ACID IN CIRCULATORY FAILURE ${ }^{1}$
}

By JONATHAN MEAKINS AND C. N. H. LONG

(From the Department of Medicine, McGill University Clinic, Royal Victoria Hospital, Montreal)

(Received for publication February 1, 1927)

The following investigation was undertaken in an attempt to ascertain some of the chemical changes in the functioning tissues which might develop from circulatory failure especially those which concern oxygen and lactic acid. The disturbances of cellular metabolism which occur in circulatory failure have occupied a considerable amount of attention in recent years. This subject has been chiefly studied in regard to the changes in the carbon dioxide content and combining power of the blood or to the changes in oxygen content of the arterial or venous blood. These observations have contributed to our knowledge of some of the results and compensations which are consequent upon failing circulation but have not explained many of the phenomena which occur in this condition. Since the principle symptoms in early disturbances of the circulation are produced by muscular effort, it seems reasonable to associate certain of them with related functions in the muscles themselves, more especially because investigations performed heretofore did not explain the cause of these symptoms. The investigations of Hill and Meyerhof and their co-workers into the physiology of muscular work indicated that similar observations in persons with disturbed circulation might help to elucidate this problem. We have therefore repeated phases of their work in cases with disturbed circulation and have compared them with normal individuals under similar circumstances

Circulatory failure may be defined as a state in which the volume of blood circulated per unit of time is not adequate for the physical needs of the moment. These needs may vary over a considerable

${ }^{1}$ Read before the Annual Meeting of the Association of American Physicians, at Atlantic City, May 4, 1926. 
range of activities from that of complete rest up to considerable physical and mental activity. The point at which physical effort becomes embarrassed differs in different individuals. The question of a normal point or degree is impossible of an answer. The work accomplished with ease by a youth of twenty could not be done by a man of sixty except with considerable effort and distress. A conspicuous difference would, furthermore, be found in men of twenty in their capacity to do heavy physical work. This would be dependent upon their "training," or in great part upon the functional efficiency of their circulation. We consider that the normal capacity for physical effort should be taken to be the amount of work which can be accomplished by the average individual, taking into consideration his age, sex, and previous training. It will be found that all so-called healthy individuals may be grouped between the trained athlete on the one extreme and the untrained sedentary worker on the other. But there would be no reason to believe that the one could not be made into the other provided there were no pathological condition which would interfere. If one were present, the individual could not be classified as healthy.

When one comes to consider the capacity for physical exertion in conditions of circulatory disease, a still further graded result is obtained. There are those cases which are little, if at all, different from the normal, but from this point cases may show all degrees of impaired circulatory function down to those where life is maintained with difficulty, and eventually death ensues from an inadequate volume of blood circulated. Cases in all degrees of circulatory failure were investigated during the course of the work to be reported It was natural that only those with a comparatively moderate degree of circulatory deficiency were found to be capable of carrying out the exercise experiments. The quantitative results obtained clearly indicated, however, the progressive character of the process. Only cases with an uncomplicated rheumatic cardiac lesion were used for the exercise experiments, as it was considered essential that as far as possible cases in which there were lesions in other organs should be excluded in order not to complicate the observations. Among the cases in which lactic acid determinations only were done the circulatory failure was due to a variety of lesions. 


\section{METHODS}

The principles of the methods employed in this work have already been elaborated in published experiments of a similar type on normal individuals (1), (2) and (3). The Douglas Bag method was employed throughout and determinations of oxygen consumption, debt and requirement were made in exactly the same manner as was employed in these previous experiments.

Two forms of exercise were used, namely, walking and standing-running. It is well known that individuals with cardiac disease of any severity are unable to exert themselves to the same extent that normal persons can and the degree of these two exercises is consequently mild when judged by normal standards. As will be seen later, as far as the patients themselves were concerned, even the "mild" exercises produced the same effects as are observed in and after severe exercise in healthy people. Consequently the rate of walking was in most cases reduced to about $3 \frac{1}{2}$ miles per hour, and standing-running was done at 184 steps per minute.

Another precaution to which special attention had to be paid in these cases was that no exercise of any kind should be undertaken before the preliminary resting oxygen consumption was determined. We were much puzzled at first by the differences in our initial and final resting oxygen consumption values, in spite of the fact that we had allowed what in normal individuals was an adequate preliminary resting period. It eventually transpired that where these differences occurred the patients lived outside the hospital and had walked up the short hill from the street to the laboratory before the determination was made. This apparently mild exercise was quite sufficient to cause these variations. Following this experience we chose as our subjects hospital patients who had been lying in bed twelve or more hours before the experiment was performed and who were brought in a wheel chair from their ward to the laboratory when required.

The gas samples were analyzed in Henderson's modification of the Haldane apparatus, while the lactic acid in the blood was estimated by Clausen's method (4), using the modifications described by one of us (1).

\section{OXYGEN INTAKE AND REQUIREMENT}

As soon as an individual starts to take exercise of any kind the $\mathrm{O}_{2}$ intake per minute rises. The rise to the level required for the exercise is not instantaneous and is reached only after some two minutes have elapsed. Each different degree of exercise requires, furthermore, a definite amount of $\mathrm{O}_{2}$ intake which increases with the severity of the exercise, until a point is reached at which the heart and lungs are unable to meet the oxygen demand required for the 
exercise. In short, the $\mathrm{O}_{2}$ demand or requirement ${ }^{2}$ of the exercise is met until the $\mathrm{O}_{2}$ intake is at a maximum. Beyond this point the individual must go into $\mathrm{O}_{2}$ debt $^{3}$ if the exercise is to be performed. As a result of the accumulation of lactic acid during exercise extra oxygen is used during the recovery period to remove it. This extra oxygen is of course the oxygen debt and the time taken to return to a normal $\mathrm{O}_{2}$ intake is spoken of as the recovery period.

In the patient with cardiac disease we would expect two variations to occur in the above scheme. (a) In the first place, owing to the diminished output of the heart (5) (6) and (7) the amount of oxygen reaching the muscles per minute is diminished and therefore the $\mathrm{O}_{2}$ intake will be at a maximum at a lower level than it is in the normal person. (b) Secondly, again owing to this diminished output, the time required for the $\mathrm{O}_{2}$ intake to reach the level for the exercise will be longer. This will be most noticeable in exercises demanding a high level of $\mathrm{O}_{2}$ intake.

As regards this response to exercise, there is no essential difference between the cardiac patient and the normal individual: it is one of degree only. The cardiac patient is working on a lower level and this level will be lower and lower as the severity of the disease increases, until at length, as we shall see later, in entirely decompensated patients even at rest in bed the requirement may be more than the heart is able to cope with. It is simply a question of the relationship between the $\mathrm{O}_{2}$ intake and the amount of exercise that has to be done for, very probably, there is no difference between the processes required to run a mile in four minutes and to keep a normal tonicity in the muscles when at rest in bed. Both require a certain amount of oxygen per minute and if this is not available the individual is bound to go into oxygen debt and show all the symptoms associated with this condition.

\footnotetext{
${ }^{2}$ The oxygen requirement of a given effort is defined as the total oxygen used during the exercise and in complete recovery from it, reckoned from the resting level of oxygen consumption.

${ }^{3}$ The oxygen debt is determined by measuring the total oxygen used in the recovery period, starting from the end of exercise and subtracting the oxygen which would have been used in the same period had the body remained at rest throughout.
} 
JONATHAN MEAKINS AND C. N. H. LONG

TABLE 1

A. Walking experiments

\begin{tabular}{|c|c|c|c|c|c|c|}
\hline Subject & 䕒 & Date & Exercise and duration & $\left|\begin{array}{l}\text { Excess } \\
\text { Oa in } \\
\text { take* }\end{array}\right|$ & $\underset{\substack{\mathrm{O}_{2} \\
\text { ment }}}{\text { require- }}$ & $\begin{array}{l}\mathrm{O}_{\mathbf{g}} \\
\text { debt }\end{array}$ \\
\hline $\begin{array}{l}\text { L. Normal } \\
\text { male }\end{array}$ & $\begin{array}{r}\text { kilos } \\
70\end{array}$ & $\begin{array}{l}\text { March 16, } \\
1926 \\
\text { March 17, } \\
1926 \\
\text { March 19, } \\
1926\end{array}$ & $\begin{array}{l}\text { Walking at } 1.42 \text { metres per } \\
\text { second for } 7 \text { minutes } 20 \\
\text { seconds } \\
\text { Walking at } 1.7 \text { metres per } \\
\text { second for } 5 \text { minutes } 10 \\
\text { seconds } \\
\text { Walking at } 2.02 \text { metres per } \\
\text { second for } 4 \text { minutes } 16 \\
\text { seconds }\end{array}$ & $\left|\begin{array}{r}c c . \text { per } \\
\text { minute } \\
636\end{array}\right|$ & $\begin{array}{c}c c . \text { per } \\
\text { minute } \\
(750) \\
\\
(1,000) \\
\\
(1,400)\end{array}$ & $\begin{array}{l}\text { cc. } \\
177\end{array}$ \\
\hline $\begin{array}{l}\text { R. Chronic } \\
\text { mitral endo- } \\
\text { carditis with } \\
\text { stenosis and } \\
\text { insufficiency } \\
\text { (rheumatic) }\end{array}$ & 74 & $\begin{array}{c}\text { February 16, } \\
1926 \\
\text { February } 17, \\
1926 \\
\text { February } 18, \\
1926 \\
\text { February } 19, \\
1926\end{array}$ & $\begin{array}{l}\text { Walking at } 1.42 \text { metres per } \\
\text { second for } 7 \text { minutes } 24 \\
\text { seconds } \\
\text { Walking at } 1.7 \text { metres per } \\
\text { second for } 5 \text { minutes } 18 \\
\text { seconds } \\
\text { Walking at } 1.7 \text { metres per } \\
\text { second for } 3 \text { minutes } 12 \\
\text { seconds } \\
\text { Walking at } 2.02 \text { metres per } \\
\text { second for } 4 \text { minutes } 16 \\
\text { seconds }\end{array}$ & 1,380 & $(1,000)$ & 3,415 \\
\hline $\begin{array}{l}\text { Miss } H \text {. Normal } \\
\text { female }\end{array}$ & & $\begin{array}{l}\text { November 27, } \\
1925 \\
\text { December 3, } \\
1925 \\
\\
\text { December 1, } \\
1925 .\end{array}$ & $\begin{array}{l}\text { Walking at } 1.04 \text { metres per } \\
\text { second for } 7 \text { minutes } \\
\text { Walking at } 1.25 \text { metres per } \\
\text { second for } 7 \text { minutes } 30 \\
\text { seconds } \\
\text { Walking at } 1.36 \text { metres per } \\
\text { second for } 7 \text { minutes }\end{array}$ & $\begin{array}{l}670 \\
476\end{array}$ & $(600)$ & $\begin{array}{r}580 \\
620 \\
1,194\end{array}$ \\
\hline $\begin{array}{l}\text { Miss Ld. } \\
\text { Chronic mitral } \\
\text { endocarditis } \\
\text { with stenosis } \\
\text { and insuff- } \\
\text { ciency (rheu- } \\
\text { matic) }\end{array}$ & & $\begin{array}{l}\text { December 31, } \\
1925 \\
\text { December 31, } \\
1925 \\
\text { December 29, } \\
1925\end{array}$ & $\begin{array}{l}\text { Walking at } 0.96 \text { metres per } \\
\text { second for } 7 \text { minutes } \\
\text { Walking at } 0.96 \text { metres per } \\
\text { second for } 6 \text { minutes } \\
\text { Walking at } 0.96 \text { metres per } \\
\text { second for } 6 \text { minutes }\end{array}$ & $\begin{array}{l}500 \\
486\end{array}$ & 751 & $\mid \begin{array}{l}1,440 \\
1,600 \\
1,400\end{array}$ \\
\hline
\end{tabular}

* The excess oxygen intake is the extra oxygen used per minute over and above the resting oxygen intake. 
TABLE 1-Continued

B. Standing-running at 184 steps per minute

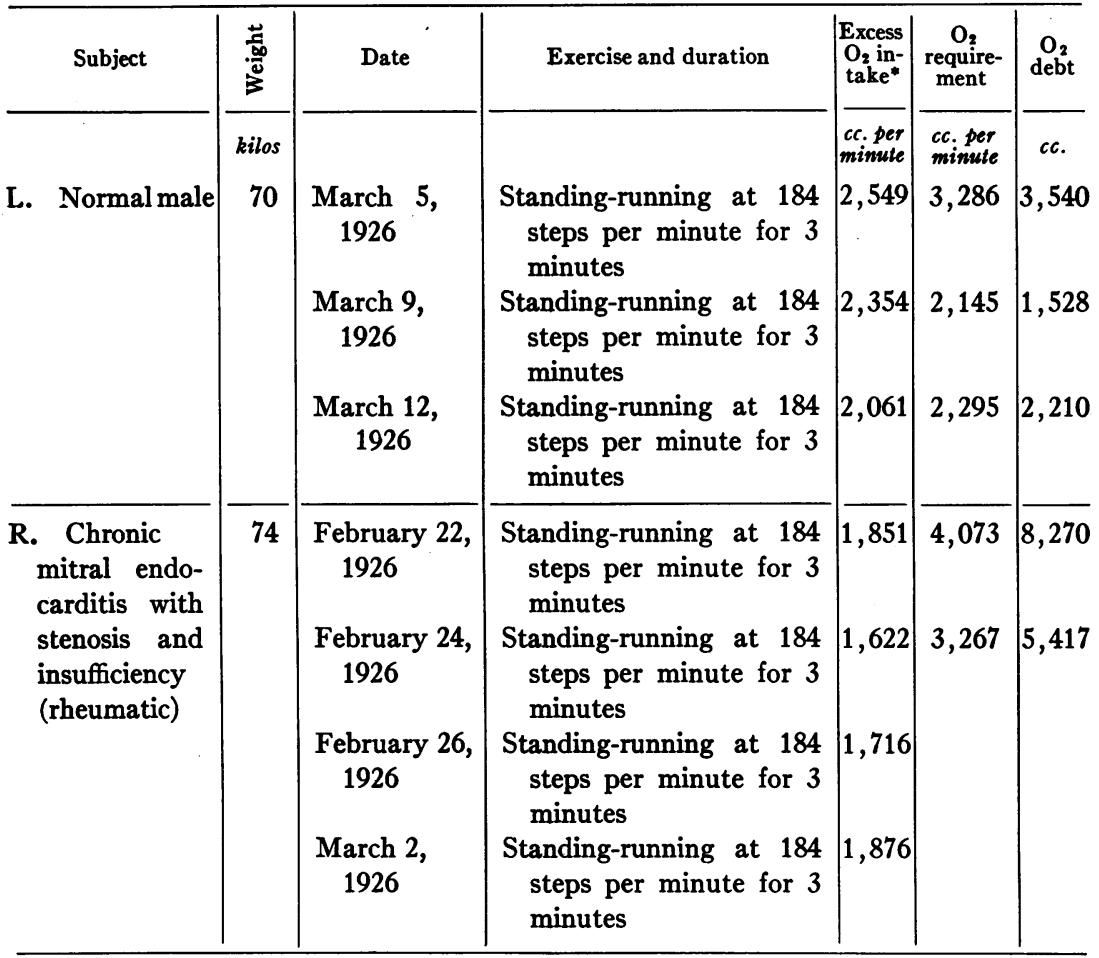

We have studied this relationship between $\mathrm{O}_{2}$ intake and $\mathrm{O}_{2}$ requirement in patients ${ }^{4}$ with moderately severe cardiac lesions and compared the findings with those obtained on normal individuals. Both males and females were used as subjects. The results of our experiments are seen in table 1. Some of the data (in parentheses) are taken from earlier experiments on H. L. (3, p. 168, fig. 2) and represent figures for a normal individual of about 70 kilos weight. These approximate estimations are indicated by being in parentheses.

Let us consider first the results of the walking experiments on $\mathrm{L}$ and $R$. At all the observed speeds $L$ is obviously not distressed.

${ }^{4}$ Observations were carried out on a large series of cases but only a few complete results are recorded here in detail. All of the experiments revealed the same general results but varied in degree in different cases. 
His oxygen intake is well below its maximum value, that is to say about 4.0 liters per minute ( 3 , p. 156, table 1$)$ and the requirement (3, p. 168, fig. 2) of the exercise is met with ease so that the $\mathrm{O}_{2}$ debt acquired is small and his recovery rapid. $R$ presents a very different picture. In his case, although his $\mathrm{O}_{2}$ intake for the different speeds is approximately the same as L's, yet his $\mathrm{O}_{2}$ debt is much larger, and at the highest rates of walking is very large when it is considered that the maximum speed studied is only 2.02 meters per second, i.e., about $4 \frac{1}{2}$ miles per hour. If we assume, as we have, that the $\mathrm{O}_{2}$ requirement of the exercises is the same in his case as in L's, then the only explanation for these large debts is that his circulation responds much more slowly to the demands of the exercise than it does in the normal individual. This means that although he finally comes into equilibrium he takes so long to do it, compared with a normal man, that a considerable oxygen debt has time to accumulate. This, as we shall see, does occur (cf. fig. 1). In the case of the females, $H$ and Ld, an exactly similar result was obtained.

In the standing-running experiments in addition to this second factor, the first factor which was predicted seems to come into operation, that is to say, the lower limit of the maximum oxygen intake in cardiac disease. These experiments are possibly not as accurate as the walking ones since in the latter uniformity of exertion is more easily obtained. Every endeavor was made, however, in the standing-running experiments to secure this by warning and instructing the subjects to lift their knees to the same height at each step. This was arbitrarily set at a point where the thigh was flexed to a right angle with the body. The objective symptoms on exercise were in themselves significant. L did exercise at the set rate, that is to say 184 steps per minute, with practically no discomfort, and soon recovered afterwards. $\mathrm{R}$, on the other hand, was always greatly distressed and usually had to be more or less driven to complete it. In addition his recovery was long and was initially marked by exhaustion and dyspnea. These signs are reflected in the results for $\mathbf{R}$. L's oxygen intake averaged around 2.3 liters a minute and his oxygen debt around 2.4 liters (table $1 \mathrm{~B}$ ), while the respective values for $\mathbf{R}$ were 1.8 and 6.8 liters respectively (table $1 \mathrm{~B}$ ). In view of the large $\mathrm{O}_{2}$ debt we can assume that about 1.8 liters a minute is R's maximum 
oxygen intake and since the oxygen requirement is around 3.0 to 3.5 liters a minute this in itself would account for all or a large part of the observed debt, and when considered along with the increased debt due to the circulatory lag is about the expected value.

\section{TABLE 2}

Subject L. Normal. Aged 25. Weight 70 kilos. Post-absorptive*

Exercise: Standing-running 184 steps a minute for 3 minutes

Initial respiratory exchange $\frac{\mathrm{CO}_{2}}{\mathrm{O}_{2}}=\frac{240}{281}=0.85$

\begin{tabular}{c|c}
\hline Mid point of sample & Excess $\mathrm{O}_{2}$ intake \\
\hline seconds & cc. per minute \\
7.5 & 869 \\
22.5 & 1,549 \\
37.5 & 2,079 \\
52.5 & 2,139 \\
75 & 2,629 \\
105 & $2,144(?)$ \\
135 & 2,890 \\
165 & 2,629 \\
\hline
\end{tabular}

Subject $R$. Chronic endocarditis with mitral stenosis and insufficiency (rheumatic). Aged 34. Weight 74 kilos. Post-absorptive

Exercise: Standing-running 184 steps a minute for 3 minutes

Initial respiratory exchange $\frac{\mathrm{CO}_{2}}{\mathrm{O}_{2}}=\frac{208}{266}=0.78$

\begin{tabular}{c|c}
\hline Mid point of sample & Excess $\mathrm{O}_{2}$ intake \\
\hline seconds & cc. per minute \\
7.5 & 472 \\
22.5 & 784 \\
37.5 & 1,028 \\
52.5 & 1,183 \\
75 & 1,419 \\
105 & 1,608 \\
135 & 1,719 \\
165 & 1,796 \\
\hline
\end{tabular}

* The term post-absorptive implies that the subject had been without food for at least twelve hours before the experiment.

Hill, Long and Lupton in their papers (1), (2) and (3) class exercise at this speed as a moderate one which should have an oxygen 
debt of 2 to 3 liters and a recovery period of 30 minutes. As seen above, $L$ fulfills this but $R$ presents quite definitely the picture of an individual who has undertaken severe exercise comparable in the normal individual to standing-running at a much higher speed than has been carried out in the experiments reported here, that is to say, 237 steps per minute for about the same time. It is interesting to note that $\mathrm{R}$ was tried at this rate and found quite incapable of performing it for more than a few seconds.

In order to test the second postulate that one of the causes for the

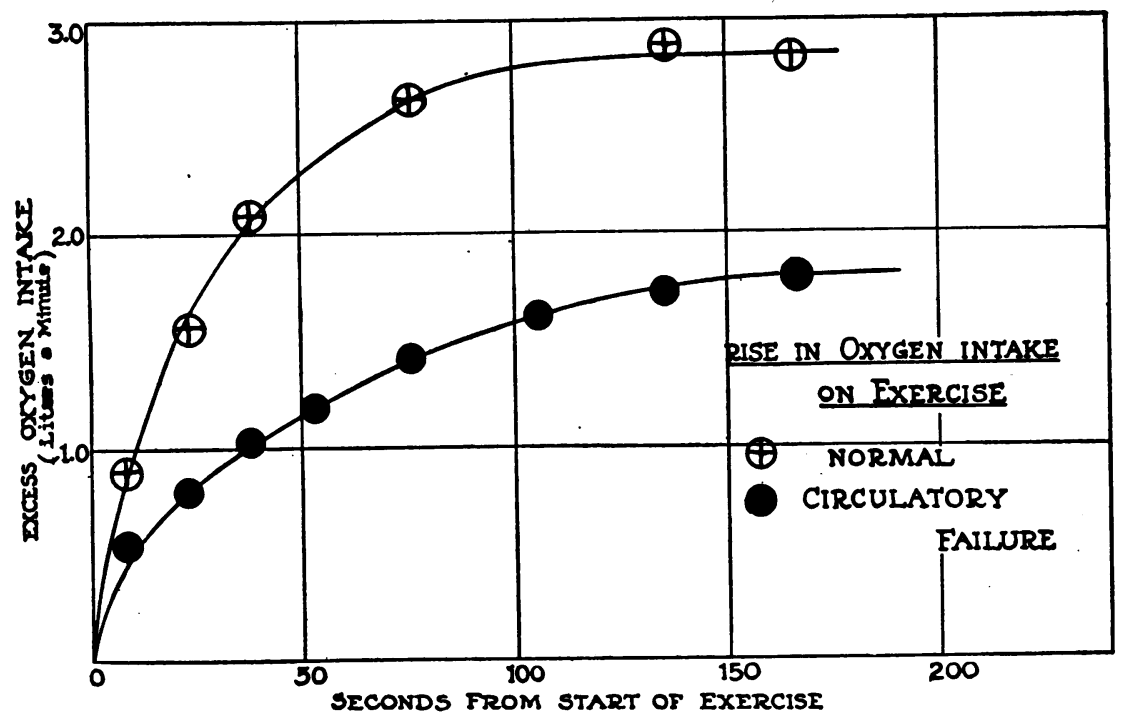

Fig. 1. Chart of Data in Table 2

increased oxygen debt in the cardiac cases was the circulatory lag in the response to exercise, we have determined the rise in oxygen intake on exercise in such cases and also in normal individuals. The results are in table 2 and figure 1.

These show quite clearly the greater initial lag in the cardiac patient's response to exercise. The curve in these cases lacks the smart initial response that is seen in the normal and is altogether a much slower and gradual rise to a maximum. Naturally, the greater level of $\mathrm{O}_{2}$ intake reached by the normal rather exaggerates the dif- 
ference between the curves; nevertheless, allowing for this, the difference in the shape of the curves is obvious.

\section{OXYGEN DEBT IN CIRCULATORY DISEASE}

This has already been considered to some extent in the preceding section, and we have seen that for a given exercise this quantity is greater in individuals with circulatory disease than it is in normal persons, owing to the slower circulation rate in the former. If the maximum oxygen debts are considered, we find that the above order of magnitude is reversed. The maximum $\mathrm{O}_{2}$ debt of an individual represents the greatest extent to which he can drive his musculature

TABLE 3

Maximum oxygen debts

\begin{tabular}{|c|c|c|c|c|c|}
\hline \multicolumn{3}{|c|}{ (a) Normal individuals } & \multicolumn{3}{|c|}{ (b) Cardiac cases } \\
\hline Subject & Exercise & $\mathrm{O}_{2}$ debt & Subject & Exercise & $\mathrm{O}_{2}$ debt \\
\hline \multirow{7}{*}{$\begin{array}{l}\text { A. V. H. } \\
\text { C. N. H. I. } \\
\text { D. T. } \\
\text { T. A. L. }\end{array}$} & \multirow{7}{*}{$\begin{array}{l}\text { Running fast for } 8 \\
\text { minutes } \\
\text { Stool jumping for } 2 \\
\text { minutes } \\
\text { Running } \frac{1}{4} \text { mile very fast } \\
\text { Standing-running "all } \\
\text { out" for } 3 \frac{1}{2} \text { minutes }\end{array}$} & \multirow{7}{*}{$\begin{array}{l}\text { liters } \\
10.9 \\
10.5 \\
13.2 \\
10.1\end{array}$} & & \multirow{6}{*}{$\begin{array}{l}\text { Standing-running } 184 \\
\text { steps per minute "all } \\
\text { out" for } 3 \frac{1}{2} \text { minutes } \\
\text { Standing-running } 184 \\
\text { steps per minute "all } \\
\text { out" for } 3 \frac{1}{2} \text { minutes }\end{array}$} & liters \\
\hline & & & $\mathbf{R}$ & & 5.4 \\
\hline & & & & & \\
\hline & & & B & & 6.0 \\
\hline & & & & & \\
\hline & & & & & \\
\hline & & & $\mathbf{R}$ & $\begin{array}{l}\text { Standing-running } 184 \\
\text { steps per minute "all } \\
\text { out" for } 3 \frac{1}{2} \text { minutes }\end{array}$ & 8.4 \\
\hline
\end{tabular}

before total exhaustion occurs. In other words it is the greatest accumulation of lactic acid the body will tolerate. This definition would imply that this quantity was independent of the circulation and, theoretically, it is. In addition, by actual experiment, it has been shown that when exhaustion is reached the muscles contain about as much lactic acid as does an isolated muscle when stimulated until it will no longer respond. Theoretically then, we should expect to find that by long continued exercise the cardiac patient would develop a maximum oxygen debt equal to that of a normal individual, the only difference being the rate at which it was accumulated owing, of course, to the slower circulation rate. Practically, our cardiac 
cases have never shown values for a maximum $\mathrm{O}_{2}$ debt anywhere approaching those that have been recorded for normal individuals. Table 3 shows maximum values in the two cases.

\section{TABLE 4}

Subject L. Normal. Aged 25. Weight 70 kilos

Exercise: Standing-running at 184 steps a minute for 3 minutes

Resting respiratory exchange $\frac{\mathrm{CO}_{2}}{\mathrm{O}_{2}}=\frac{248}{277}=0.89$

\begin{tabular}{c|c}
\hline Mid point of interval & Excess O, intake \\
\cline { 2 - 2 } 0 & cc. per minute \\
$15^{\prime \prime}$ & 2,321 \\
$1^{\prime}$ & 1,690 \\
$2^{\prime} 30^{\prime \prime}$ & 737 \\
$5^{\prime} 30^{\prime \prime}$ & 77 \\
$8^{\prime}$ & 54 \\
$15^{\prime} 30^{\prime \prime}$ & 45 \\
$26^{\prime} 30^{\prime \prime}$ & Nil \\
\hline
\end{tabular}

Subject $R$. Chronic mitral endocarditis with stenosis and insufficiency (rheumatic). Aged 34. Weight 74 kilos

Exercise: Standing-running at 184 steps a minute for 3 minutes Resting respiratory exchange $\frac{\mathrm{CO}_{2}}{\mathrm{O}_{2}}=\frac{265}{300}=0.87$

\begin{tabular}{|c|c|}
\hline Mid point of interval & Excess $\mathrm{O}_{2}$ intake \\
\hline & cc. per minute \\
\hline 0 & 1,622 \\
\hline $16^{\prime \prime}$ & 1,330 \\
\hline $1^{\prime}$ & 1,033 \\
\hline $2^{\prime} 30^{\prime \prime}$ & 351 \\
\hline $5^{\prime} 30^{\prime \prime}$ & 321 \\
\hline $8^{\prime}$ & 141 \\
\hline $15^{\prime} 30^{\prime \prime}$ & 63 \\
\hline $35^{\prime} 30^{\prime \prime}$ & 34 \\
\hline $55^{\prime} 30^{\prime \prime}$ & 2 \\
\hline
\end{tabular}

Quite probably the reason for these differences is a psychological one. The cardiac patient is aware of his infirmity and dreads to drive himself too far for fear of the consequences. 
THE RECOVERY PROCESS IN CIRCULATORY DISEASE

The foregoing considerations enable us to predict the difference in the recovery process to be found here between normal and diseased individuals. The larger oxygen debts imply a longer recovery period as also does the slower circulation rate. These theoretical considerations are well substantiated by our results, as table 4 and figure 2 show.

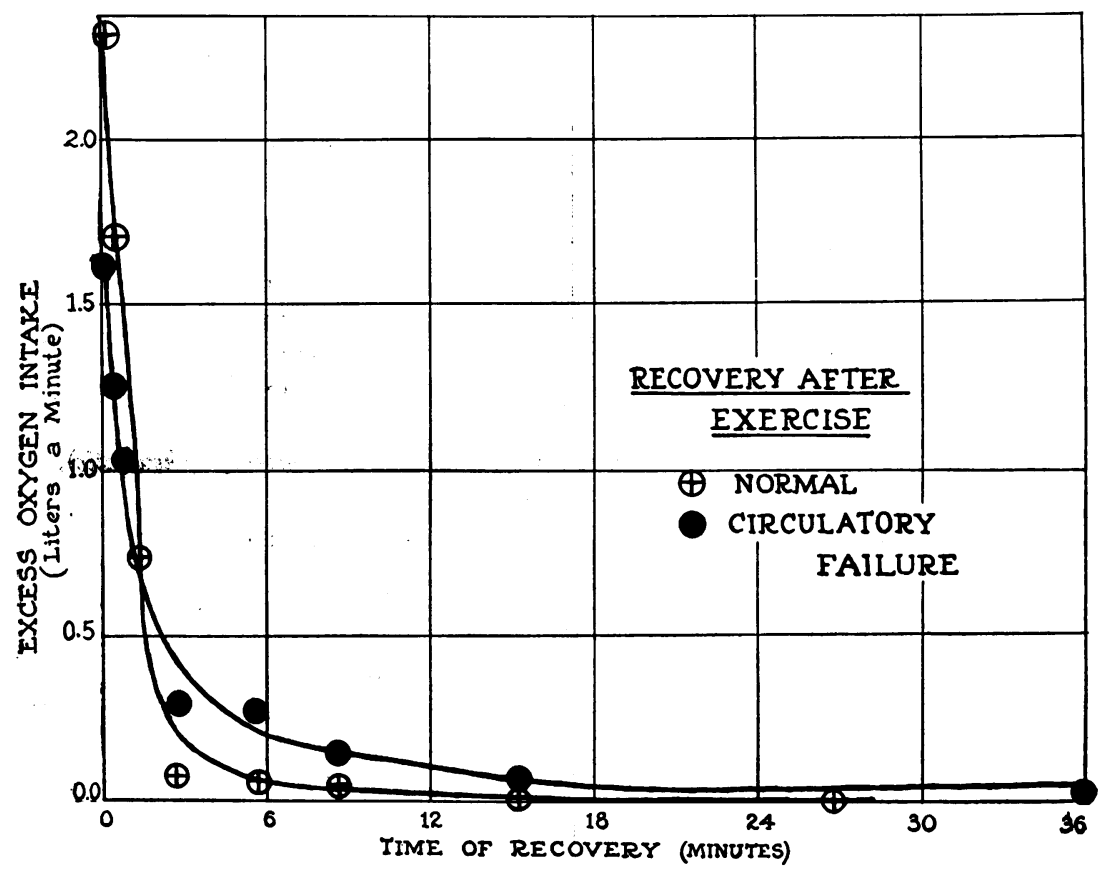

Fig. 2. Chart of Data in Table 4

The recovery period in $\mathrm{L}$ is strikingly shorter and more rapid than in $\mathrm{R}$ in spite of its higher initial level. It is easy to see that with the increasing circulatory failure recovery from even mild exercise becomes slower and more prolonged until, as we shall see in completely decompensated cases, this is so lasting as to constitute an almost "chronic" condition of oxygen debt. 


\section{LACTIC ACID IN THE BIOOD IN CIRCULATORY DISEASE}

Although this subject is considered after the respiratory phenomena, its logical position should perhaps be first, for it is the appearance and disappearance of this substance in the body during exercise that is responsible for most, if not for all, of the phenomena

TABLE 5

Lactic acid in the blood after exercise in nurmal individuals and in patients with cardiac disease

\begin{tabular}{|c|c|c|c|c|}
\hline Number & Condition & Exercise & Time of observation & $\begin{array}{l}\text { Lactic } \\
\text { acid in } \\
\text { blood }\end{array}$ \\
\hline \multirow{3}{*}{1} & \multirow{3}{*}{ Normal } & & & $\begin{array}{l}\text { mgm. per } \\
100 \mathrm{cc} .\end{array}$ \\
\hline & & Standing-running 156 & Rest & 20 \\
\hline & & $\begin{array}{l}\text { steps per minute for } 55 \\
\text { minutes }\end{array}$ & $\begin{array}{l}\text { After } 18 \text { minutes exercise } \\
\text { After } 37 \text { minutes exercise }\end{array}$ & $\begin{array}{l}58.1 \\
52.5\end{array}$ \\
\hline 2 & Normal & $\begin{array}{l}\text { Running at } 9 \text { miles per } \\
\text { hour }\end{array}$ & $\begin{array}{l}\text { Rest } \\
1 \text { minute after exercise }\end{array}$ & $\begin{array}{l}23.2 \\
54.6\end{array}$ \\
\hline \multirow[t]{2}{*}{3} & \multirow[t]{2}{*}{ Normal } & Standing-running $\quad 237$ & Rest & 21.0 \\
\hline & & $\begin{array}{l}\text { steps per minute for } 10 \\
\text { minutes }\end{array}$ & $\begin{array}{l}1 \text { minute after exercise } \\
48 \text { minutes after exercise }\end{array}$ & $\begin{array}{l}95.0 \\
41.0\end{array}$ \\
\hline 4 & Normal & $\begin{array}{l}\text { Walking at } 4.1 \text { miles per } \\
\text { hour for } 33 \text { minutes }\end{array}$ & $\begin{array}{l}\text { Rest } \\
1 \text { minute after exercise }\end{array}$ & $\begin{array}{l}21.4 \\
58.9\end{array}$ \\
\hline \multirow[t]{2}{*}{5} & \multirow{2}{*}{$\begin{array}{l}\text { Cardiac } \\
\text { disease }\end{array}$} & Walking at 3.81 miles per & Rest & 25.2 \\
\hline & & $\begin{array}{l}\text { hour for } 3 \text { minutes } 12 \\
\text { seconds }\end{array}$ & 1 minute after exercise & 59.1 \\
\hline \multirow[t]{2}{*}{6} & \multirow{2}{*}{$\begin{array}{l}\text { Cardiac } \\
\text { disease }\end{array}$} & Standing-running at 189 & Rest & 40.6 \\
\hline & & $\begin{array}{l}\text { steps per minute for } 3 \\
\text { minutes } 1 \text { second }\end{array}$ & 1 minute after exercise & 167.2 \\
\hline \multirow[t]{2}{*}{7} & \multirow{2}{*}{$\begin{array}{l}\text { Cardiac } \\
\text { disease }\end{array}$} & Standing-running at 189 & Rest & 43.6 \\
\hline & & $\begin{array}{l}\text { steps per minute for } 3 \\
\text { minutes }\end{array}$ & 1 minute after exercise & 93.0 \\
\hline \multirow[t]{2}{*}{8} & \multirow{2}{*}{$\begin{array}{l}\text { Cardiac } \\
\text { disease }\end{array}$} & Walking at 3.4 miles per & Rest & 25.3 \\
\hline & & hour for 7 minutes & 1 minute after exercise & 61.8 \\
\hline
\end{tabular}

connected with that act. The capacity for its accumulation in the muscles, and hence in the blood, enables the individual to perform exercise far beyond his contemporary oxygen supply: its removal is the essential feature of the recovery process. Whilst it is not possible to study the changes of this substance in the muscles themselves, alterations of its concentration in the blood can give us considerable 
information as to an individual's response to exercise. As a general rule, a rise of lactic acid in the blood to more than $60 \mathrm{mgm}$. per 100 cc. on exercise signifies that this exercise is causing an increasing oxygen debt, or, in others words, that it is beyond the power of the individual to perform for any appreciable length of time.

It was quite easy in our patients to take blood samples immediately at the end of exercise and to see how the lactic acid content compared with that of normal individuals under the same conditions. The results are given in table 5 .

It is apparent from this table that for a given exercise the cardiac patient has a higher level of lactic acid in his blood than has the normal person. The normal values are taken from the paper by Hill, Long and Lupton (1). This higher level necessarily implies a longer time to return to the resting value, and while this has not been actually measured our observations on the recovery time for oxygen tell us that this is actually so.

\section{OXYGEN CONSUMPTION AT REST IN CASES WITH SEVERE CIRCULATORY FAILURE}

It has been pointed out above that the recovery period from exercise may be greatly prolonged. If recovery were not complete after a night's rest in bed then it would be expected that a cumulative condition of oxygen debt would be produced. This could only be removed by continuous rest in bed and days might be required to complete the recovery period. A further and aggravated state would be that which might occur when even on prolonged rest an oxygen debt continued to develop. It might be considered possible to detect this decrease in oxygen consumption as compared to the oxygen requirement by repeated determinations of the oxygen consumption under basal conditions. But we are confronted in these abnormal states with the difficulty of determining the basal oxygen requirement. The rapid and fictitious physiological changes in weight make a theoretical standard according to surface area almost an impossibility. It therefore remains to carry out a series of almost daily estimations of the oxygen consumption irrespective of the theoretical surface area as an experiment unto itself. But this has been fraught with difficulties which are inherent in the condition. It has been 
adequately demonstrated by Peabody, Meyer and Dubois (8) that patients with advanced circulatory failure have an increased oxygen consumption under basal conditions which they attribute to the increased physical effort resulting from dyspnoea which occurs even when at complete rest. This has been confirmed by other workers. Under these circumstances it would appear to be difficult to determine a comparative oxygen requirement during the various stages of circulatory failure, as a comparative study is so far possible only in regard to the oxygen consumption. If we take as proven, therefore, that with the increased respiratory effort consequent upon a failing circulation the oxygen consumption should be increased to meet the increased oxygen requirement, we would expect a pro-

TABLE 6

Basal oxygen consumption in a case of chronic mitral endocarditis with stenosis and insufficiency with circulatory failure

\begin{tabular}{l|c|l}
\hline \multicolumn{1}{c|}{ Date } & Oxygen consumption & \multicolumn{1}{|c}{ Condition } \\
\cline { 2 - 3 } & liters per hour & \\
February 13, 1926 & 14.12 & \\
February 17, 1926 & 13.68 & Moderate decompensation \\
February 18, 1926 & 11.69 & Improving \\
February 25, 1926 & 12.68 & Improving \\
March 5, 1926 & 13.25 & Stationary \\
March 17, 1926 & 12.41 & Stationary \\
\hline
\end{tabular}

gressive increase in the basal oxygen consumption. If there is no increase, we arrive at the logical conclusion that the oxygen consumption is falling behind the oxygen requirement and results, consequently, in a progressive oxygen debt. A number of attempts were made in properly selected progressive cases to learn whether these are the facts. A typical example is shown in table 6 .

During a period of apparent improvement of the circulation, the basal oxygen consumption declined to 11.69 liters per hour. But subsequently there was a slight but consistent increase in the basal oxygen consumption to 13.25 liters. Symptoms of circulatory distress then increased and, eventually, reached a climax and serious signs of circulatory failure developed. Synchronously the oxygen consumption declined to 12.41 but other signs of oxygen debt developed. 
We are dealing here apparently with a condition where the margin of safety is very narrow and the comparatively gross methods of determination of oxygen consumption as compared with oxygen requirement are not sufficiently delicate to warrant definite conclusions. The premises upon which we would base our conclusions in regard to these findings are, furthermore, not sufficiently consistent in their interpretation to be of value. These results may be used to support an argument in two opposite directions as follows. (1) If the oxygen consumption increases, it might indicate greater deficiency in the circulation with its resultant dyspnea and accompanying increase of physical exertion. (2) On the other hand, a decrease in the oxygen consumption might indicate either a decreased need for oxygen due to improved circulation or else a complete breakdown of the circulation. It is impossible to determine therefore whether decrease in the oxygen consumption indicates a decrease in the power of the circulation to provide the tissues with a sufficient amount of oxygen to meet the average requirement, or decrease in the requirement owing to improvement in the circulation relieving the dyspnea.

LACTIC ACID IN THE BLOOD IN CIRCULATORY FAILURE AT REST

It seemed advisable therefore to seek some other index of failing circulation independent of such paradoxical interpretations as those resting upon the oxygen consumption. To obtain such we have resorted to an index of oxygen consumption in the muscle mass. It has been demonstrated by Meyerhoff (9) and Hill (10) that the oxidation of lactic acid resulting from muscular activity is dependent upon the oxygen supply to the tissues. If this be deficient and an oxygen debt occurs then there is an increase in the lactic acid in the muscles, which is eventually reflected by an increase in the lactic content of the blood.

As we have pointed out above, the state of persons with circulatory failure would seem to be equivalent to a continuation, with an accumulative effect, of the ordinary recovery processes from exercise. This could be determined either through demonstrating that the oxygen consumption is greater than the oxygen requirement or that there is a lactic acid accumulation in the blood. The former we found impossible of demonstration on account of the absence of a 


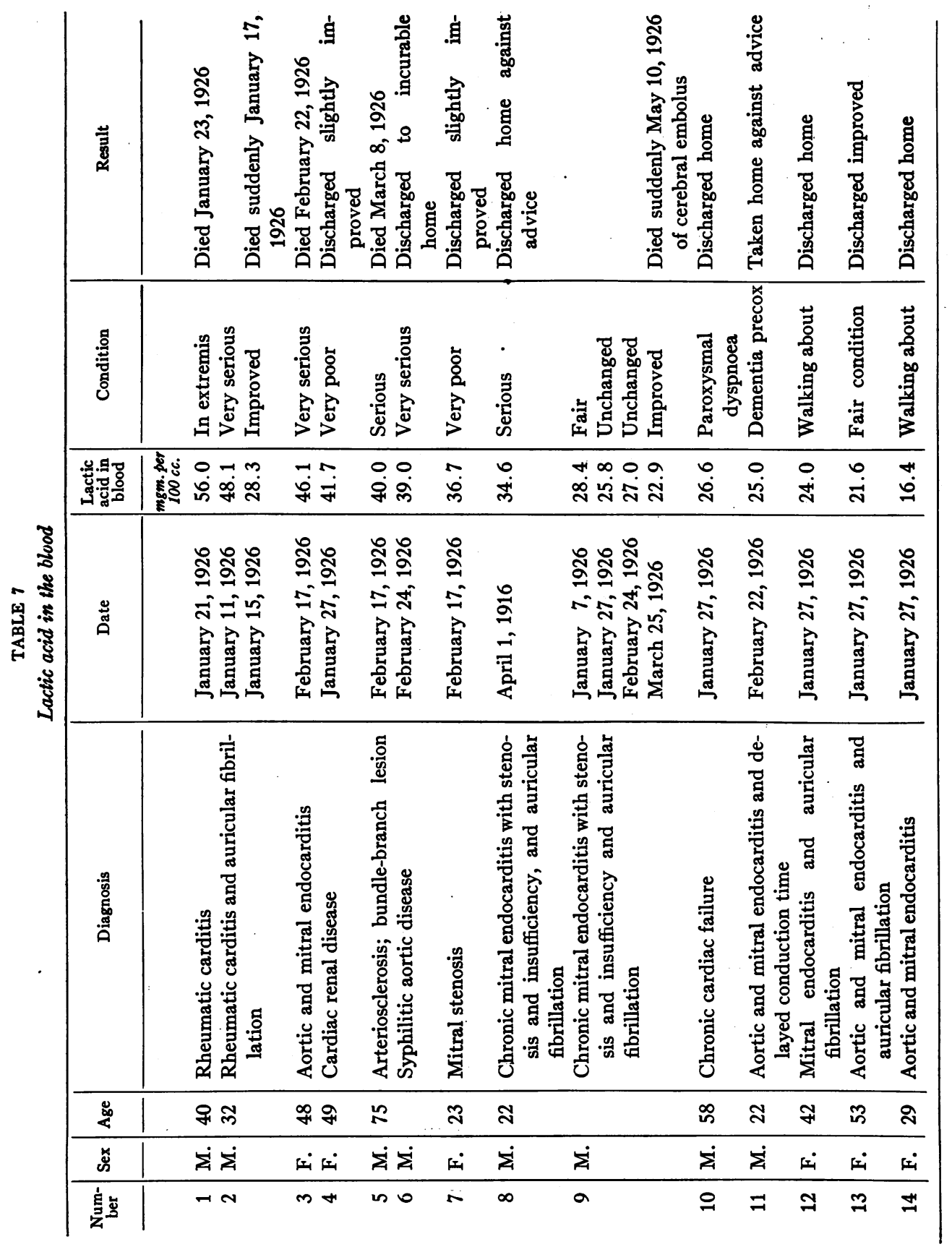


base line. The latter we could determine with accuracy. In table 7 is tabulated the lactic acid content of the blood in cases of circulatory failure of different degrees of severity.

It will be noted that the more severe the symptoms of failing circulation the higher the lactic acid percentage. With improvement in the condition of the circulation the lactic acid content of the blood appeared to return to normal level. This is well illustrated in table 8.

This patient had severe circulatory failure, due to a rheumatic

TABLE 8

Lactic acid in the blood in a case of progressive circulatory failure with exacerbations and remissions in a case of chronic rheumatic mitral endocarditis with stenosis and insufficiency

\begin{tabular}{l|r|l}
\hline Date & $\begin{array}{c}\text { Lactic acid } \\
\text { in blood }\end{array}$ & \multicolumn{1}{c}{ Condition } \\
\cline { 1 - 2 } & $\begin{array}{c}\text { mgm. per } \\
100 \text { cc. }\end{array}$ & \\
January 7,1926 & 35.8 & Symptoms of decompensation moderate \\
January 11, 1926 & 51.8 & Symptoms more severe \\
January 15, 1926 & 29.8 & General condition much improved \\
January 27, 1926 & 30.5 & Pronounced dyspnea and orthopnea \\
January 28, 1926 & 110.0 & Condition much worse almost moribund \\
January 29, 1926 & 38.7 & Great improvement in condition \\
February 17, 1926 & 35.3 & Condition has remained unchanged \\
February 24, 1926 & 30.3 & Condition unchanged \\
March 13, 1926 & 27.7 & Condition weaker more dyspnea and edema \\
March 18, 1926 & 105.1 & Condition gradually became worse, now in ex- \\
& & tremis \\
March 25, 1926 & 49.8 & Condition somewhat improved but very weak \\
March 26, 1926 & 40.3 & Condition unchanged \\
March 27, 1926 & 108.5 & Condition very bad, unconscious, died 12 hours \\
& & later \\
\hline
\end{tabular}

carditis with mitral stenosis and insufficiency. There was a succession of exacerbations of the circulatory symptoms with tricuspid insufficiency, increase of the dependent anasarca and jaundice. With each increase of the circulatory failure there was a pronounced increase of the lactic acid in the blood. This is well demonstrated in figure 3.

The increase in severity of the symptoms on each occasion was more gradual than the rapid change in the concentration of lactic acid would indicate, while the remissions were equally gradual and 
always followed treatment directed to relieve some cause of circulatory embarrassment, such as paracentesis of the peritoneum or pleura, phlebotomy or an increase in the amount of digitalis administered. The almost explosive character of the lactic acid fluctuations seems to indicate that points were reached in the degree of circulatory failure where the margin of safety had practically disappeared. For analogy they may be compared to the course of events in a healthy man during running. In such a person the lactic acid content of the

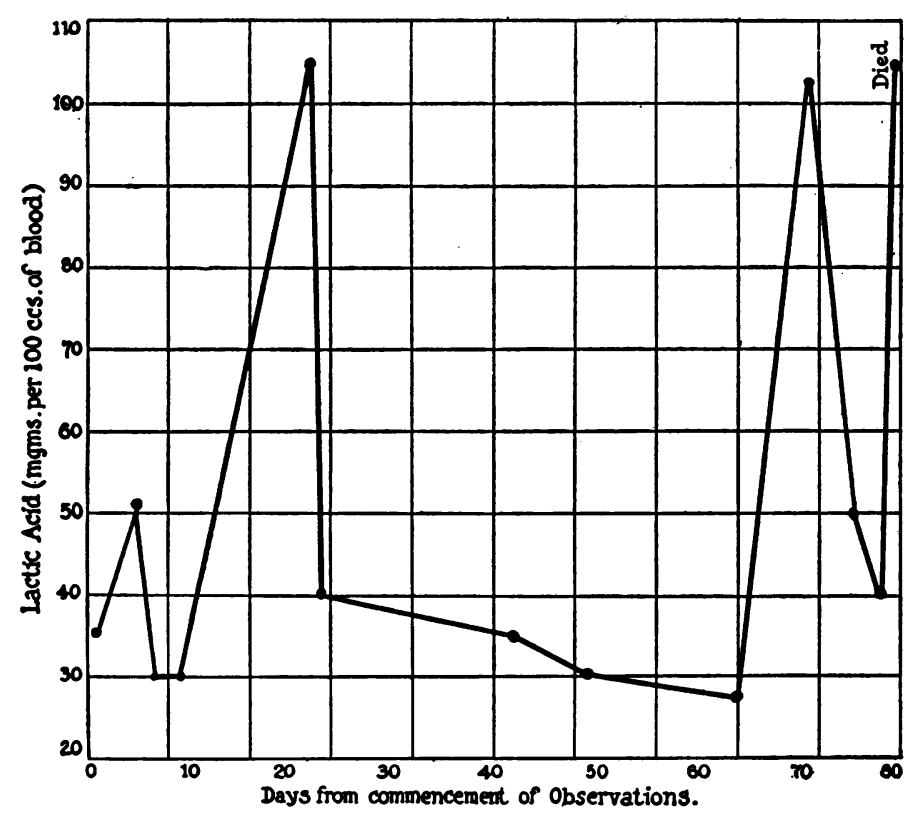

Fig. 3. Lactic Acm in the Blood in the Case of Chrontc Rheumatic Endocarditis, the Data on.Whom Are Given in Table 8

blood may remain constant, but at a higher level than normal provided he be in a steady state. If now the exercise be increased so that the steady state is not maintained then a rapid lactic acid accumulation occurs. The situation would appear to be similar in patients with severe circulatory failure. A steady state is maintained at rest, but with a higher level of lactic acid than the resting healthy person. If instead of increasing the exercise the circulation be reduced, then the steady state is no longer maintained and a rapid lactic acid accumulation occurs. It is shown in figure 3 how the 
recovery period after each exacerbation of circulatory failure becomes longer and less complete than after the previous one.

It is suggested that the ultimate cause in circulatory failure may be due to lactic acid accumulation in the myocardium. The experiments of Katz, Kerridge and Long (11) demonstrate that the muscle of the heart is less capable of acting as a buffer than is the skeletal muscle. Lactic acid accumulation leads to decreased power of concentration which in the case of the myocardium produces a decreased blood supply which in turn leads to further lactic acid accumulation. Thus a vicious circle ensues which tends to perpetuate itself but which promptly ceases once it has been cut by allowing the circulation to improve in spite of the increase of lactic acid. The manner in which this may be brought about varies in different cases.

\section{THE INFLUENCE OF LACTIC ACID ACCUMULATION IN DYSPNEA}

From time to time there has been controversy as to whether in circulatory failure the dyspnea so commonly found is due to an increase of the $\mathrm{H}$-ion concentration of the blood. Lewis, Ryffel, Cotton and Barcroft (12) came to the conclusion through observing a shift in oxyhemoglobin curves to the right that an increase in $\mathrm{H}$-ion concentration did occur. They were unable however to demonstrate the presence of lactic, $\beta$-oxy-butyric or other acid in the blood. This was probably due to the technical difficulties encountered at that time. But even the pronounced increase of lactic acid found in the cases here reported would not be sufficient except in the most severe instances to produce a conspicuous shift in either the carbon dioxide or oxy-hemoglobin dissociation curves. It must be appreciated, however, that the concentration of lactic acid in the blood is but a reflection of the accumulation of lactic acid in the tissues from which it has escaped. The processes which are occurring in the tissues produce the signs and symptoms of circulatory failure and these develop in large part from a defective blood supply.

\section{CONCLUSIONS}

1. The response of an individual with circulatory failure is the same as that of a normal individual except in the following details:

$a$. There is a lag in the rise of oxygen intake to the level required for the exercise. 
b. The maximum oxygen intake is set at a lower level than in a normal person for the same exercise.

$c$. The recovery period from exercise is more prolonged.

$d$. The rise in the lactic acid level of the blood is greater on a given exercise than in normal individuals.

2. It was found impracticable to use basal oxygen consumption to determine a relation between oxygen intake and oxygen requirement.

3. Severe circulatory failure is accompanied by an increased rise in the level of the resting lactic acid in the blood.

4. This accumulation of lactic acid in the blood is in proportion to the severity of the circulatory failure.

\section{BIBLIOGRAPHY}

1. Hill, A. V., Long, C. N. H., and Lupton, H., Proc. Roy. Soc., 1924, Series B, xcvi, 438. Muscular Exercise, Lactic Acid and the Supply and Utilization of Oxygen. Parts I-III.

2. Hill, A. V., Long, C. N. H., and Lupton, H., Proc. Roy. Soc., 1924, Series B, xcvii, 84. Muscular Exercise, Lactic Acid and the Supply and Utilization of Oxygen. Parts IV-VI.

3. Hill, A. V., Long, C. N. H., and Lupton, H., Proc. Roy. Soc., 1924, Series B, xcvii, 155. Muscular Exercise, Lactic Acid and the Supply and Utilization of Oxygen. Parts VII-VIII.

4. Clausen, S. W., Jour. Biol. Chem., 1922, lii, 263. A Method for the Determination of Small Amounts of Lactic Acid.

5. Meakins, J. C., and Davies, H. W., Respiratory Function in Disease. Edinburgh, 1925.

6. Lundsgaard, Garvin and Van Slyke, Jour. Exp. Med., 1918, xxvii, 65, 87 and 129. Studies of Lung Volume.

7. Rabinowitch, I. M., Arch. Int. Med., 1925, xxxvi, 239. The Output of the Heart per Beat in Heart Disease.

8. Peabody, F. W., Meyer, A. L., and Dubois, E. F., Arch. Int. Med., 1916, xvii, 980. Clinical Calorimetry. XVI. The Basal Metabolism of Patients with Cardiac and Renal Disease.

9. Hill and Meyerhof, Ergeb. d. Physiol., 1923, xxii, 299. Utter die Vorgänge bei der Muskelkontraktion.

10. Hill, A. V., Muscular Activity, Herter Lectures. Baltimore, 1924.

11. Katz, L. N., Kerridge, P. T., and Long, C. N. H., Proc. Roy. Soc., 1926, Series B, xcix, 26. Lactic Acid in Mammalian Cardiac Muscle. III. Changes in Hydrogen-ion Concentration.

12. Lewis, Thomas, Ryffel, J. N., Wolf, C. G. L., Cotton, T., and Barcroft, Joseph, Heart, 1913, v, 45. Observations Relating to Dyspnea in Cardiac and Renal Patients. 